\title{
Prolonged Expression of AP-1 Transcription Factors in the Rat Hippocampus after Systemic Kainate Treatment
}

\author{
K. R. Pennypacker, L. Thai, J.-S. Hong, and M. K. McMillian \\ Neuropharmacology Section, National Institute of Environmental Health Sciences, National Institute of Health, Research \\ Triangle Park, North Carolina 27709
}

\begin{abstract}
Systemic administration of kainate, a glutamate receptor agonist, caused neuronal death in the CA1 and CA3 fields of the rat hippocampus. In the areas of cell loss, reactive astrocytes increased their expression of an astrocyte-specific protein, glial fibrillary acidic protein (GFAP). AP-1 DNA binding activity and the expression of a $35 \mathrm{kDa}$ fos-related antigen (fra) remained elevated in the rat hippocampus for at least 2 weeks after a single systemic injection of kainate, which correlated with changes in gene expression during reactive gliosis. Immunoreactivity for fras was detected in the nuclei of neurons in the dentate gyrus, but relatively few cells in CA1 and CA3 were immunoreactive 1 week after kainate treatment. However, elevated AP-1 DNA binding activity was observed in the CA1 and CA3 regions as well as in the dentate gyrus, suggesting that proteins other than the fras were involved in the astrocytic AP-1 complex. The AP-1 DNA binding activity in hippocampus recognized an AP-1 sequence from the promotor region of the GFAP gene, suggesting that GFAP is a potential target gene. Thus, a single systemic injection of kainate causes long-term activation of AP-1 DNA binding activity in the rat hippocampus and may be important for long-term changes in gene expression in hippocampal cells.
\end{abstract}

[Key words: fos-related antigen, jun, cell death, gliosis, reactive astrocyte, DNA binding activity]

The inducible AP-1 transcription factors include the fos-related antigen (fra) and jun protein families (Morgan and Curran, 1991). These factors form dimers that bind to specific DNA sequences in the promotor region of target genes to modulate gene expression. A variety of stimuli in many different tissues induce AP-1 transcription factors to regulate gene expression. In the CNS, seizure activity caused by many different stimuli induces AP-1 transcription factors in the brain, particularly in the hippocampus (Dragunow and Robertson, 1987; Morgan et al., 1987; White and Gall, 1987; Sonnenberg et al., 1989a,b; SakauraiYamashita et al., 1991; Simanato et al., 1991; Pennypacker et al., 1993a).

Systemic administration of kainic acid, a glutamate receptor agonist, causes robust and recurrent seizures in the rat. Within 90 min of KA administration, fra immunoreactivity is induced

\footnotetext{
Received Oct. 4, 1993; revised Dec. 27, 1993; accepted Jan. 13, 1994.

We are grateful to Drs. L. H. Lazarus and J. P. O'Callaghan for reviewing this manuscript.

Correspondence should be addressed to Dr. K. R. Pennypacker, NIEHS, MD 14-06, P.O. Box 12233, Research Triangle Park, NC 27709.

Copyright (C) 1994 Society for Neuroscience $0270-6474 / 94 / 143998-09 \$ 05.00 / 0$
}

in the neurons of the dentate gyrus (Le Gal La Salle, 1988; Popovici et al. 1990). Fra immunoreactivity in the CA1-CA3 areas of the hippocampus is delayed until $3 \mathrm{hr}$ after $\mathrm{KA}$ administration.

Another consequence of systemic KA administration is neuronal damage in the CA1 and CA3 regions of the hippocampus $2 \mathrm{~d}$ after treatment. During neuronal damage, astroglial cells undergo morphological and biochemical changes; these glia are called reactive astrocytes. Astrocytic markers, such as S100 protein and glial acidic fibrillary protein (GFAP), as well as neuropeptides, growth factors, and cytokines are expressed at high levels in reactive astrocytes (Fddleston and Mucke, 1993) and the enhanced expression of glia-derived protease nexin 1 persists tor at least 1 year after neuronal damage in the CAl (Nitsch et al., 1993).

In this study, we have used systemic KA treatment to kill neurons in the CA1 and CA3 fields in order to examine the long-term expression of AP-1 transcription factors during reactive gliosis.

\section{Materials and Methods}

Animals and treatments. All animals were treated in strict accordance with the NIH Guide for the Humane Care and Use of Laboratory Animals and were approved by the Animal Care and Use Committee at the Institute. Male Fischer rats (Charles River, Raleigh, NC) were kept on a 12:12 hr light:dark cycle and fed ad libitum.

Adult rats were injected intraperitoneally with $\mathrm{KA}(8 \mathrm{mg} / \mathrm{kg})$. These rats were observed at $10 \mathrm{~min}$ intervals for the presence or absence of generalized convulsions as repeated bouts of head nodding, unilateral, and bilateral forelimb clonus with intermittent episodes of whole-body clonus. Rats were killed by decapitation at different times and the brains rapidly removed for dissection of selected regions. Dissected regions were placed on crushed ice and then rapidly frozen on dry ice before storage.

Western blot analysis. Hippocampi from treated rats were homogenized and nuclear protein extracts were prepared as described (Sonnenberg et al., 1989a). One hippocampus was used for each nuclear extract. Forty micrograms of protein extract were separated on $10 \%$ sodium dodecyl sulfate (SDS)-polyacrylamide gels and transferred onto nitrocellulose membranes, and the resulting blot blocked in phosphate-buffered saline (PBS) containing 3\% skim milk for 30 min. Blots were incubated overnight at $4^{\circ} \mathrm{C}$ with either antibodies against c-fos and fras (a gift from M. Iadarola, NIH Bethesda, MD; Young et al., 1991) at a 1:500 dilution, or antibodies against the c-jun protein (Oncogene Science, Uniondale, NY) at a 1:50 dilution. The antibody against the c-jun protein was raised in a rabbit, using a synthetic peptide containing the DNA binding domain of this protein. After washing in PBS, membranes were incubated with biotinylated goat anti-rabbit antibodies for $1 \mathrm{hr}$ followed by incubation with avidin-biotin-conjugated horseradish peroxidase (Vectastain kit, Vector, Burlingame, CA) at room temperature. After washing, the blots were incubated in ECL chemiluminescence reagent (Amersham, Arlington Heights, IL) and placed against Amersham Hyperfilm, and the film was processed. 


\section{Control}

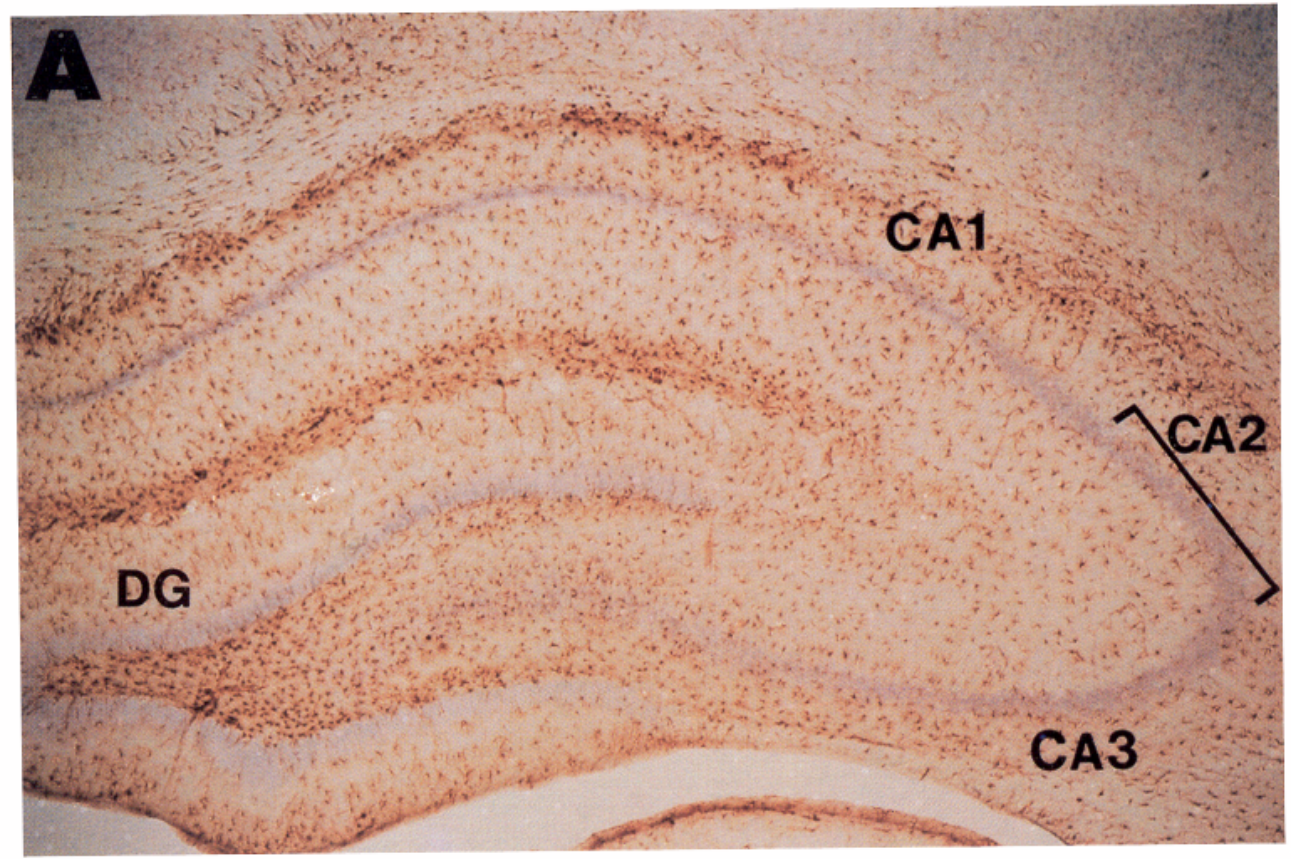

KA

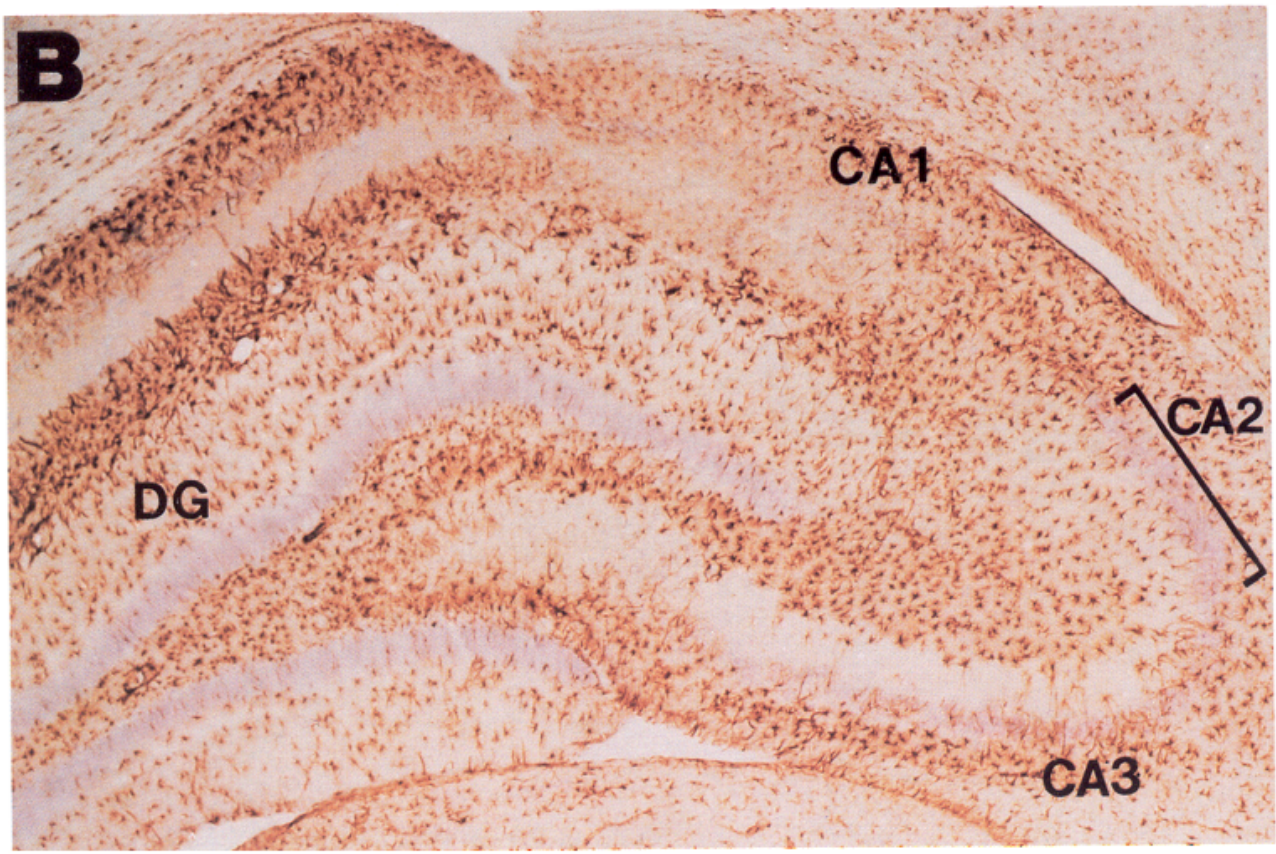

Figure 1. GFAP immunostaining in the rat hippocampus 1 week after KA administration. Rats were injected with $\mathrm{KA}(8 \mathrm{mg} / \mathrm{kg})$ or with saline as controls. Rat hippocampi were examined immunohistochemically for GFAP using antibodies at a dilution of 1:1000; the sections were counterstained with thionin to reveal the neuronal layers of the hippocampus. Magnification, $100 \times$.
Gel electrophoresis DNA binding assay. The AP-1 consensus oligomer used in this study (22-mer; 5'-CTAGTGATGAGTCAGCCGGATC$\left.3^{\prime}\right)$ contains the consensus sequence ( $5^{\prime}$-TGAGTCA-3') and was purchased from Strategene (La Jolla, CA). The GFAP AP-1 oligomer (20-mer; 5'-TGCCCAGTGACTCACCTTGG-3') was purchased from Research Genetics (Huntsville, AL). Double-stranded oligomers were labeled with $\gamma^{32}$ P-ATP using $10 \mathrm{U}$ of T4 kinase (U.S. Biochemical, Cleveland, $\mathrm{OH})$.

Binding reactions $(30 \mu \mathrm{l})$ were performed at room temperature and reaction mixtures contained $40 \mu \mathrm{g}$ of protein, $20 \mathrm{~mm}$ Tris- $\mathrm{HCl}(\mathrm{pH} 7.8$ ), $100 \mathrm{~mm} \mathrm{NaCl}, 5 \mathrm{~mm} \mathrm{MgCl}$, 1 mM EDTA, $5 \mathrm{~mm}$ dithiothreitol, $50 \mu \mathrm{g} /$ $\mathrm{ml}$ of bovine serum albumin (BSA), $100 \mu \mathrm{g} / \mathrm{ml}$ of sonicated salmon sperm DNA, $10 \%$ glycerol, and approximately $0.1 \mathrm{ng}\left(5 \times 10^{4} \mathrm{cpm}\right)$ of specified probe. Protein-DNA complexes were separated on a $5 \%$ nondenaturing polyacrylamide gel. Gels were run at $150 \mathrm{~V}$ in $50 \mathrm{~mm}$ Tris$50 \mathrm{~mm}$ boric acid/1 mM EDTA, dried, and autoradiographed overnight. For characterization of AP-1 DNA binding activity, the nuclear protein extracts were preincubated for $10 \mathrm{~min}$ prior to the addition of 
A.

AP1 DNA Binding Activity

C1 C2 K1 K2

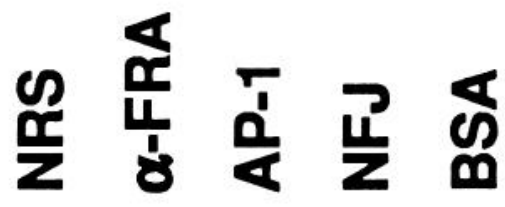
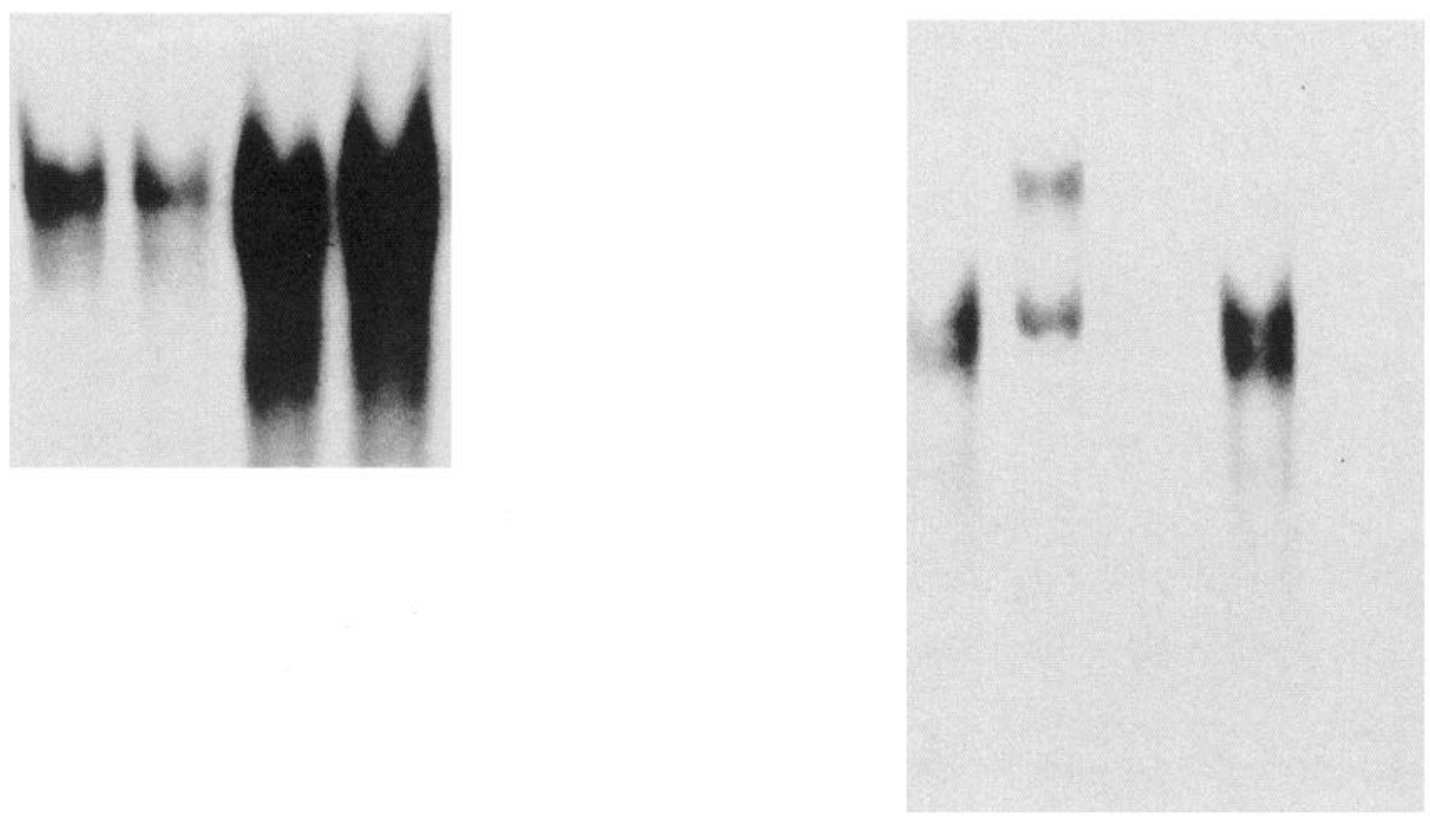

c.

\section{Western Blot}

\section{$\begin{array}{llll}\text { C1 } & \text { C2 } & \text { K1 } & \text { K2 }\end{array}$}

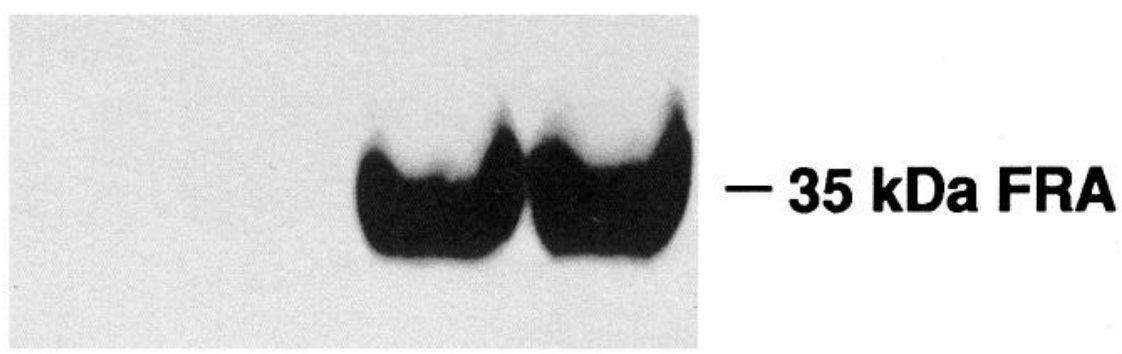

D.

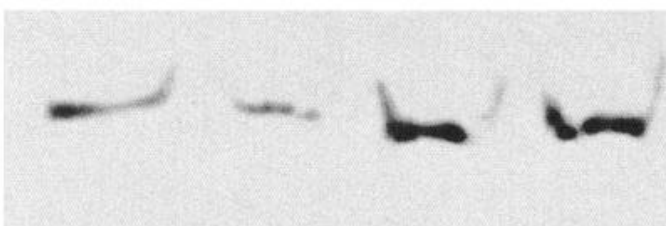

- 39 kDa c-Jun

Figure 2. Expression of AP-1 transcription factors in the rat hippocampus 1 week after KA treatment. Hippocampal nuclear extracts ( $40 \mu \mathrm{g})$ from control saline-injected $(C 1, C 2)$ rats and from $\mathrm{KA}$-injection rats $(K 1, K 2)$ were analyzed by gel shift assays $(A$ and $B)$ or by Western blots $(C$ and $D$ ). $A$, AP-1 DNA binding activity in extracts from two control and two KA-treated rats using the consensus AP-1 DNA element. $B$, In order to characterize AP-1 DNA binding activity, extracts from KA-treated rats were preincubated with a 100 -fold excess of unlabeled AP-1 oligomer ( $A P$ 1 ) or antibodies that recognize fra proteins $(\alpha-F R A)$. As controls for nonspecific binding, 100 -fold excess of an unrelated oligomer $(N F J)$, normal rabbit serum $(N R S)$, or bovine serum albumin $(B S A)$ was used. Western blots were probed with antibodies against fra proteins $(C)$ or $c$-jun protein (D). 
labeled probe with a 100 -fold excess of unlabeled AP-1 oligomer or antibodies specific to the fra proteins at a dilution of 1:500, which is the optimal concentration to supershift the AP-1 DNA binding complex that contains fra immunoreactivity. The antibody binds to the transcription factor and forms a supercomplex containing antibody:transcription factor:DNA. "Supershift" refers to the retarded migration of the antibody:transcription factor:DNA binding complex relative to the transcription factor:DNA complex in the nondenaturing gel. As controls, nuclear extracts were incubated with normal rabbit serum or a 100-fold excess of an unlabeled NFJ oligomer ( 5 '- TAGGGGTGGAGTCTCCATG-3', from Research Genetics, Huntsville, AL; a sequence that is unrelated to the AP-1 sequence, but is recognized by $\mathrm{NF} K \mathrm{~B}$ transcription factors in the promotor region of the c-jun gene).

Immunohistochemistry. Animals from each group were perfused transcardially with a $50 \mathrm{ml}$ syringe containing $1 \%$ paraformaldehyde $(30$ $\mathrm{ml} / 100 \mathrm{gm}$ body weight) followed quickly by $4 \%$ paraformaldehyde ( 70 $\mathrm{ml} / 100 \mathrm{gm}$ body weight). Brains were then removed, stored in $4 \%$ paraformaldehyde overnight, and cut as $30 \mu \mathrm{m}$ horizontal free-floating sections. Prior to overnight incubation in primary antibody, sections were prewashed in $0.2 \%$ Triton $X-100$ for $15 \mathrm{~min}$, followed by $2 \%$ normal goat serum. After a $24 \mathrm{hr}$ incubation with the primary antisera, sections were incubated with the secondary biotinylated antisera (1:400 dilution) for $1 \mathrm{hr}$. The sections were then immersed in avidin-biotin complex (Vector, Burlingame, CA) for $1 \mathrm{hr}$. Sections were always washed $3 \times$ with phosphate-buffered saline $(\mathrm{pH} \mathrm{7.4)}$ between each incubation step. 3,3'-Diaminobenzidine was used as the chromogen (Sar, 1985). The dilution for both fra (from M. Iadarola, NIDR) and GFAP antibodies (Dakopatts, Denmark) was 1:1000.

\section{Results}

To induce neuronal damage, rats were injected intraperitoneally with $8 \mathrm{mg} / \mathrm{kg} \mathrm{KA}$ and killed at the indicated times. Several animals were examined for neuronal death and reactive gliosis in the CAI and CA3 fields of the hippocampus. The neurons of the CA2 are insensitive to kainate-induced damage, so this region is used as a control for the pyramidal neuronal layers (Fig. 1 $A, B$, brackets). Thionin staining of the hippocampus from control rats shows intact neuronal layers (Fig. $1 A$ ). Hippocampi from rats 1 week after KA treatment showed very little staining in the $\mathrm{CA} I$ and $\mathrm{CA} 3$ regions, consistent with $\mathrm{KA}$-induced neuronal damage (KA, Fig. $1 B$ ), and normal staining in neuronal laycrs of the dentate gyrus (DG) and CA2. Immunostaining for GFAP was dramatically increased in astroglia surrounding the $\mathrm{CA} 1$ and CA 31 week after $\mathrm{KA}$ administration.

During the KA-induced neuronal damage, modulation of gene expression in the hippocampus occurs as indicated by changes in the transcription factors that regulate these genomic events. The AP-1 transcription factor expression and DNA binding activily, which are induced by kainate administration (Sonnenberg et al., 1989a; Pennypacker et al., 1993a), were examined for any correlation with potential target genes. Hippocampal nuclear extracts from rats 1 week after $\mathrm{KA}$ treatment were examined for elevated levels of AP-1 transcription factors. AP-1 DNA binding activity was utilized as a measure of AP-1 proteins capable of modulating gene expression since some tissues express these transcription factors but have no DNA binding activity (Pennypacker et al., 1992b). Hippocampal nuclear extracts from rats 1 week after $\mathrm{KA}$ administration containcd a considerably higher level of DNA binding activity than extracts from control rats (Fig. 2A). Characterization of this DNA binding activity showed that a 100 -fold excess of unlabeled AP-1 oligomer blocked the binding, while a 100-fold excess of an unrelated oligomer had no effect, indicating that the binding activity is specific for an AP-1 sequence (Fig. 2B). Antibodies that recognize the fra proteins supershifted the DNA:protein complex, proving that fra proteins are a component of the AP-1 DNA binding complex. Normal rabbit serum had no effect on the DNA binding. Finally, incubation of the probe with BSA was used as a control to show no nonspecific binding.

Western blot analysis was utilized to detect any changes in the expression of fra or c-jun proteins. Fra antibodies revealed a dramatic increase in a $35 \mathrm{kDa}$ protein in hippocampal extracts from rats 1 week after treatment with KA (Fig. $2 C$ ). On a Western blot probed with c-jun antibodies, this $39 \mathrm{kDa}$ transcription factor was increased only moderately in hippocampal extracts from rats 1 week after KA administration (Fig. 2D).

The time course for the induction of AP-1 transcription factors was examined for up to 2 weeks after $\mathrm{KA}$ administration. The AP-1 DNA binding activity was increased severalfold in hippocampal extracts within $4 \mathrm{hr}$ after $\mathrm{KA}$ administration and remaincd clcvated for at lcast 2 weeks after treatment (Fig. 3A). Immunoreactivity for 55 (c-fos), 46, and $35 \mathrm{kDa}$ fras increased remarkably in extracts from rats $4 \mathrm{hr}$ after KA treatment (Fig. $3 B$ ). By $1 \mathrm{~d}$ after KA treatment, only the 46 and $35 \mathrm{kDa}$ fras were detected, while at $3 \mathrm{~d}$ and later, the $35 \mathrm{kDa}$ fra was the only protein expressed. In contrast, c-jun immunoreactivity increased rapidly to maximal levels at $4 \mathrm{hr}$ and slowly declined to nearly undetectable levels at 2 weeks after treatment (Fig. $3 C$ ).

The use of whole hippocampi for the nuclear extracts does not permit the regional localization of the DNA binding activity. Therefore, hippocampi from rats 1 week after KA administration were microdissected into the dentate gyrus, CA1, and CA3 before nuclear extracts were prepared. All three regions contained elevated AP- 1 DNA binding activity (Fig. $4 A$ ). In contrast, the immunoreactivity to the $35 \mathrm{kDa}$ fra was dramatically higher in the dentate gyrus than the other two regions (Fig. $4 B$ ). Consistent with the Western blot data, antibodies that recognize the fra proteins caused a major supershift in AP-1 DNA binding activity in dentate extracts, while only a minor supershift in the bands was detected using CA1 and CA3 extracts (Fig. 4C). However, the antibodies did interfere with the AP-1 DNA binding in CA3 extracts.

Immunostaining was utilized to observe the cellular distribution of the $35 \mathrm{kDa}$ fra in the hippocampus 1 week after KA administration. In the hippocampus from control rats, very little, if any, fra immunostaining was detected, but the neuronal layers of the hippocampus were readily visible with thionin staining (Fig. 5A). One week after KA, the thionin staining in the $\mathrm{CA} 1$ and $\mathrm{CA} 3$ regions was absent, indicating the loss of neurons, while the neuronal layers of the dentate gyrus, CA2, and subiculum were still easily visualized (KA, Fig. $5 B$ ). Immunostaining for the fra protein was observed primarily in the dentate gyrus supporting the Western blotting data. The neuronal layer of the $\mathrm{CA} 2$ region between the $\mathrm{CA} 1$ and $\mathrm{CA} 3$ is largely unaffected but contains some scattered fra immunoreactivity (Fig. $5 C, D$, arrowheads). The fra nuclear immunostaining in the CAl was localized in the neuronal layer (Fig. $5 C$, arrow) with a few scattered cells showing nuclear staining. In the CA3, nuclear staining was scattered (Fig. 5D). Most of the cells containing nuclear fra immunoreactivity were counterstained with thionin (Fig. $5 D$, small arrowheads); however, a few fra-immunoreactive cells were not counterstained (Fig. $5 D$, arrows).

Double immunostaining with fra and GFAP antibodies was utilized to observe any reactive astroglia staining for fra protein. In the CA1 or CA3, large flat GFAP-positive cells did not express fra immunoreactivity (Fig. $5 E$, small arrowhead); though 


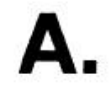

\section{4H 1D 3D 7D 2W}

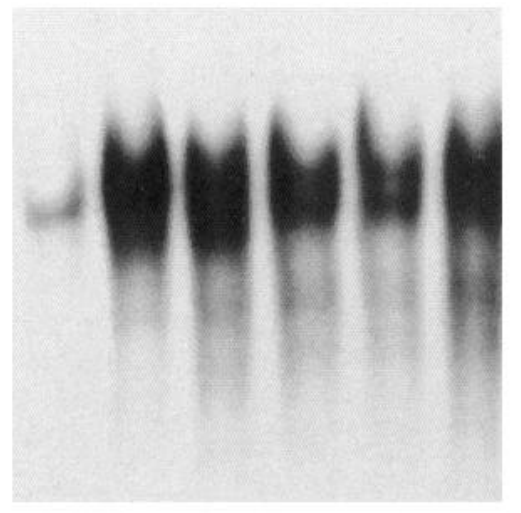

\section{AP-1 DNA binding}

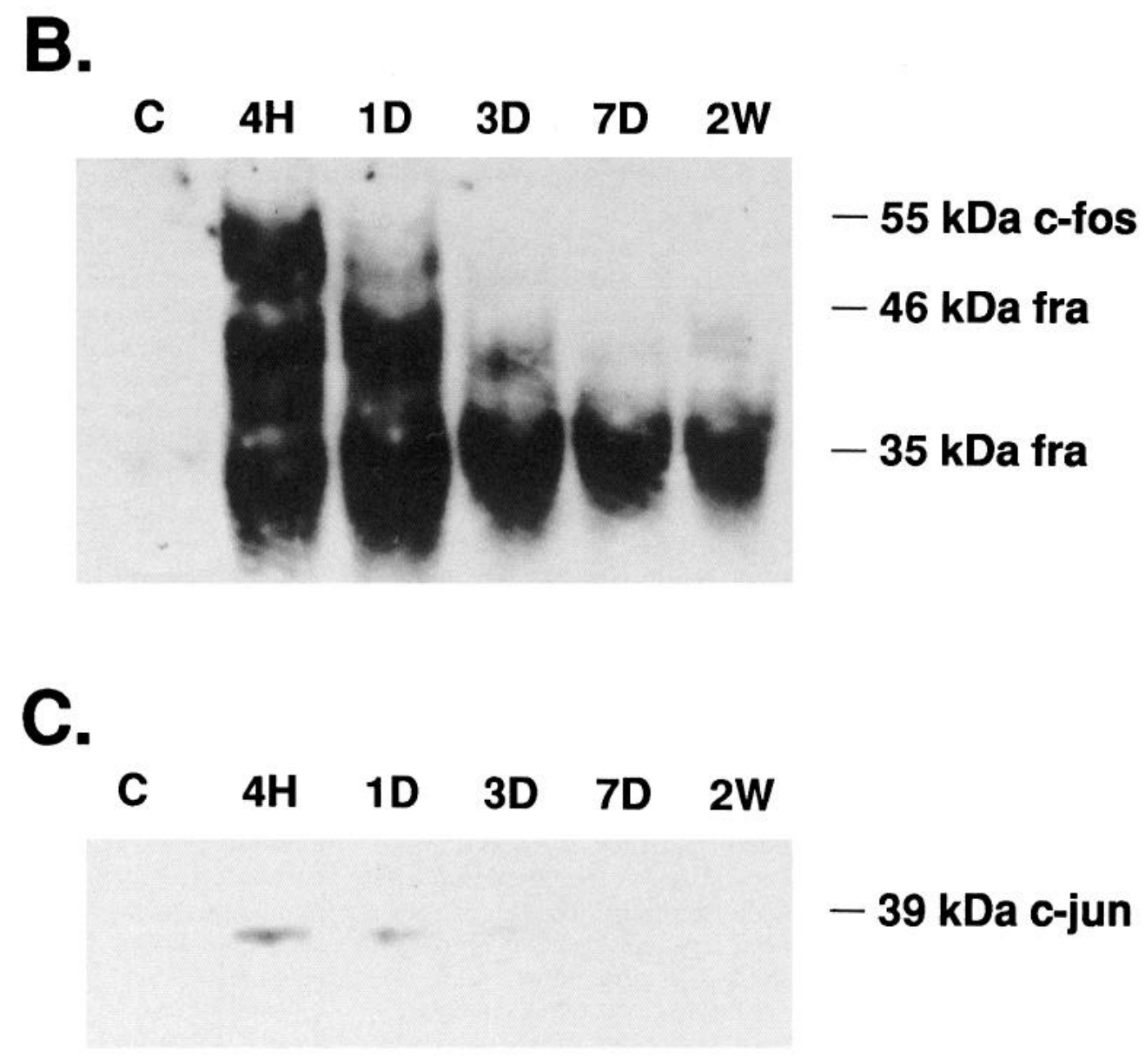

Figure 3. Time course of the expression of AP-1 transcription factors in rat hippocampus after KA administration. Nuclear extracts $(40 \mu \mathrm{g})$ from rat hippocampi after saline injection $(C)$ or 4 hr $(4 H), 1 \mathrm{~d}(I D), 3 \mathrm{~d}(3 D), 7 \mathrm{~d}(7 D)$, or 2 weeks $(2 W)$ after KA administration were analyzed for AP-1 DNA binding activity with gel shift assay $(A)$ or with Western blots probed with antibodies specific for fra proteins $(B)$ or c-jun protein $(C)$.

an occasional smaller GFAP-positive cell (Fig. $5 E$, small arrow) did stain positively for fra protein. However, a population of these cells located in the hilar region between DG and CA3 were consistently double labeled (Fig. $5 F$, small arrow).

One of the potential target genes for AP-1 DNA binding activity is the GFAP gene, so an AP-1 DNA sequence from the promotor region of the GFAP gene was used as a probe for gel shift assays. The DNA binding activity for the GFAP AP-1 sequence increased in hippocampal extracts from rats 1 week after KA administration (Fig. 6). Unlabeled consensus AP-1 oligomer (100-fold excess) competed out the binding to the GFAP AP-1, and antibodies to fra proteins supershifted the DNA:protein complex, demonstrating that this sequence can be recognized by AP-1 transcription factors. 
A.

AP-1 DNA Binding DG CA1CA3

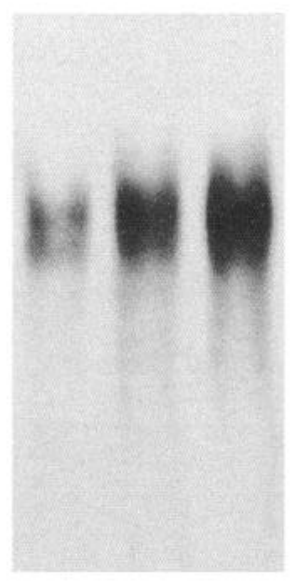

Fra Immunoreactivity

\section{DG CA1 CA3}

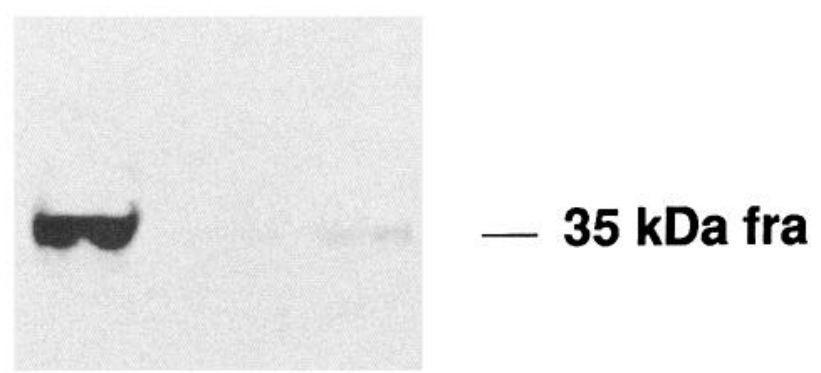

C.

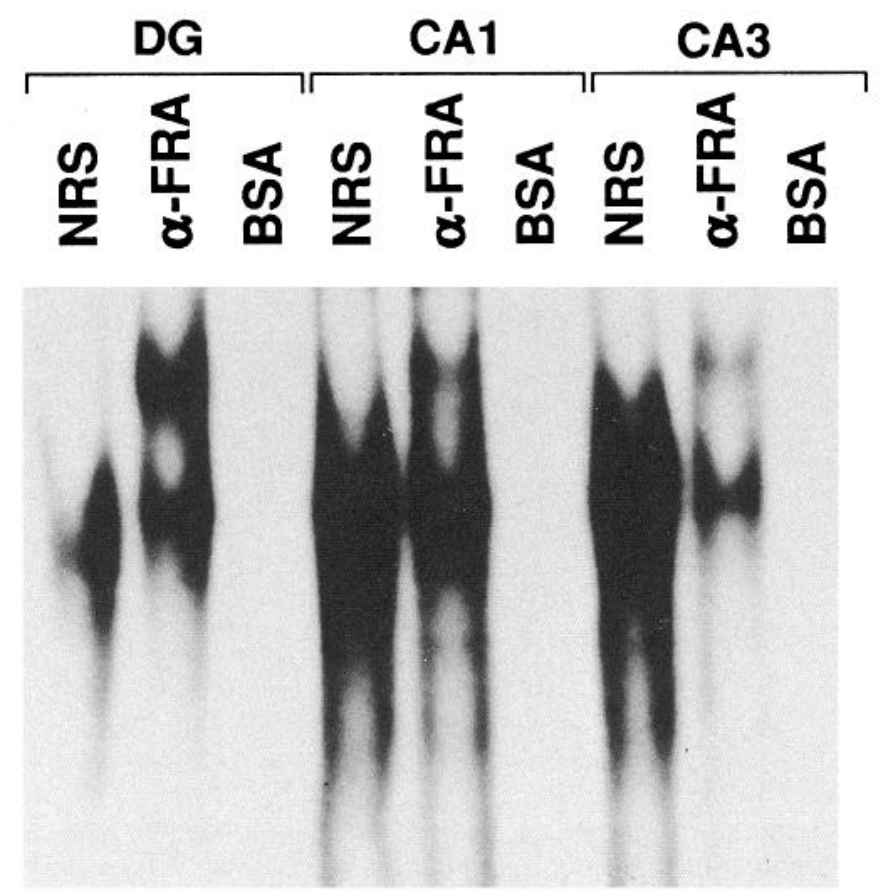

Figure 4. AP-1 transcription factors in subregions of the rat hippocampus 1 week after kainate treatment. Hippocampi from four rats 1 week after KA treatment were microdissected into $\mathrm{CA} 1, \mathrm{CA} 3$, and the dentate gyrus and the same regions from each hippocampus were pooled for nuclear extracts. Nuclear extracts were analyzed for AP-1 DNA binding activity using the gel shift assay $(A)$ and for fra immunoreactivity using Western blotting $(B)$. The composition of the AP-1 DNA binding complex in the different subregions was analyzed for fra proteins by preincubating the extracts with antibodies specific to the fra proteins $(C)$. Normal rabbit serum $(N R S)$ did not affect binding, and bovine serum albumin was run as a control to show no nonspecific binding to the AP-1 probe.

\section{Discussion}

Systemic KA administration results in neuronal damage in the $\mathrm{CA} 1$ and $\mathrm{CA} 3$ regions of the hippocampus with subsequent reactive gliosis in these areas. AP-1 DNA binding activity and the expression of a $35 \mathrm{kDa}$ fra is elevated in the hippocampus at least 2 weeks after KA administration. The fra immunoreactivity is localized in the neurons of the dentate gyrus and a 
Control

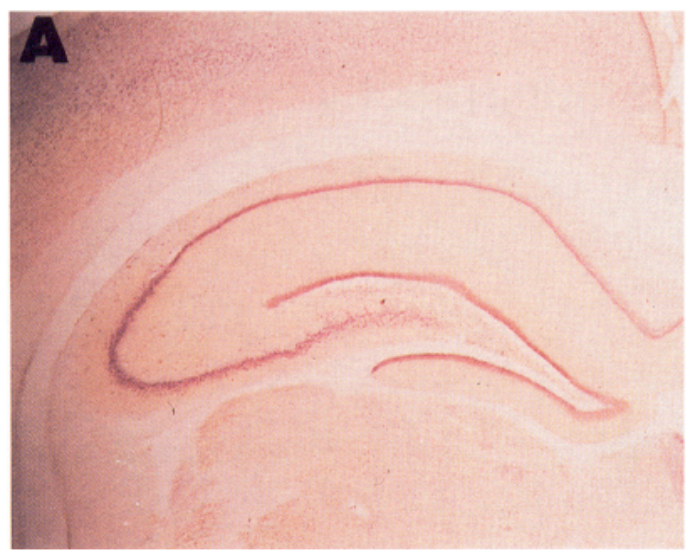

CA1

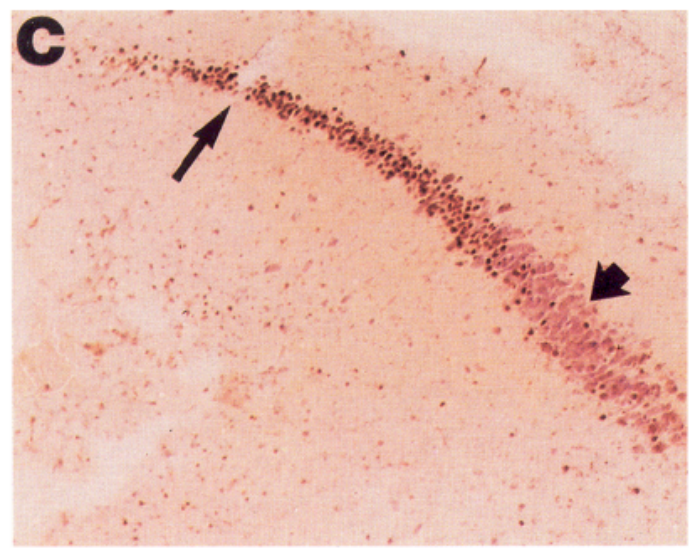

KA

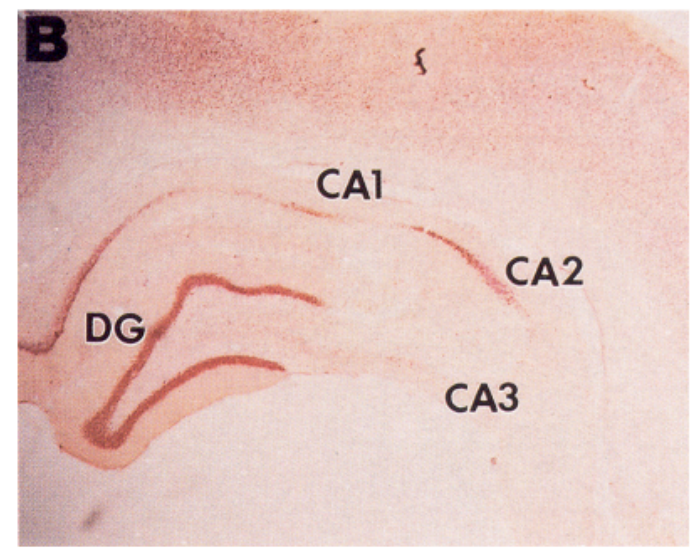

CA3

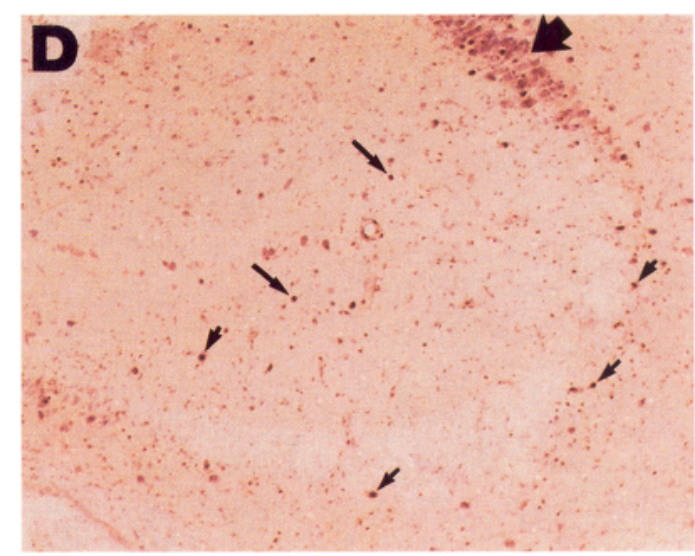

DS Immunostaining
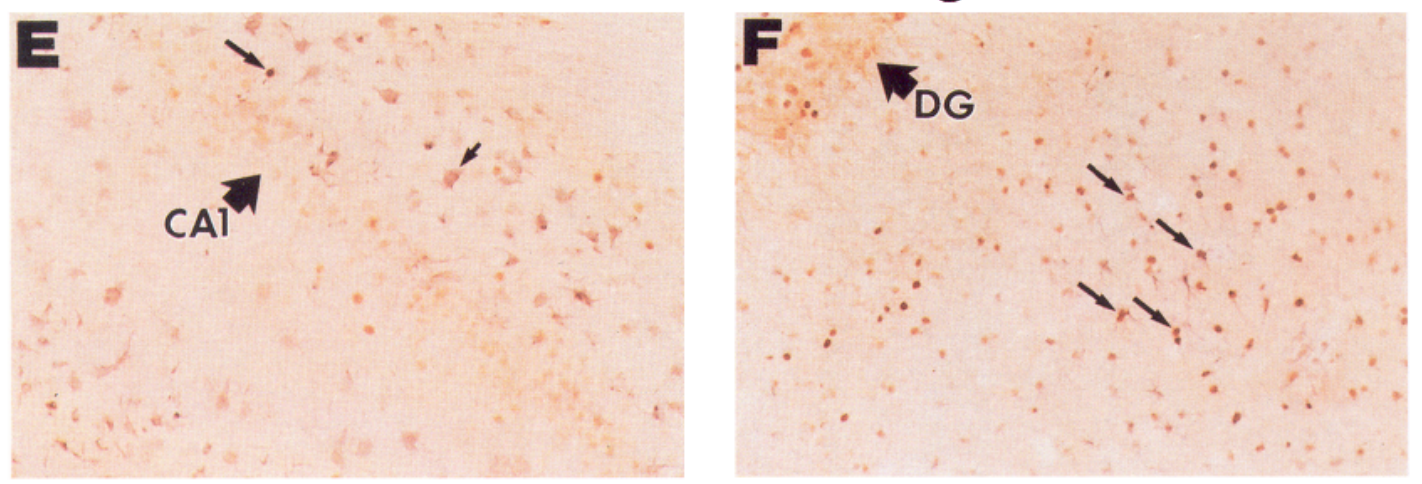

Figure 5. Immunostaining of fra protein in the rat hippocampus 1 week after KA treatment. One week after a single injection of kainate ( 8 mg/ $\mathrm{kg}$ ), rat brains were sectioned and hippocampi immunostained with antibodies specific for fra transcription factors (1:2000) followed by a thionin counterstain. Hippocampal sections from saline-injected rats were used as controls (Control). Neuronal layers of the hippocampus are stained with thionin. The CA1 and CA 3 fields are shown with a large arrowhead indicating the CA2 region. The arrow in the CA1 shows intense fra staining in the degenerating neuronal layer. The small arrowheads in the CA3 depict fra-positive thionin-positive cells, while small arrows denote frapositive thionin-negative cells. Some sections were double immunostained with the fra and GFAP antibodies. Large, flat GFAP-positive cells did not contain fra immunoreactivity (small arrowhead) in the CA1. A few small GFAP-positive cells did stain positively for fra antigen in the CA1 (arrow), and several of these cells were located between the DG and CA3 (arrows). Magnification: $A$ and $B, 40 \times ; C-F, 200 \times$.

few reactive astroglia also appear to express this protein. However, there is considerable AP-1 DNA binding activity in the $\mathrm{CA} 1$ and $\mathrm{CA} 3$ regions, suggesting that this activity may be modulating reactive glial gene expression such as GFAP. The GFAP
AP-1 sequence is an important regulatory site for this gene (Masood et al., 1993).

The expression of the AP-1 transcription factors and their DNA binding activity in most tissues is transient. Surprisingly, 


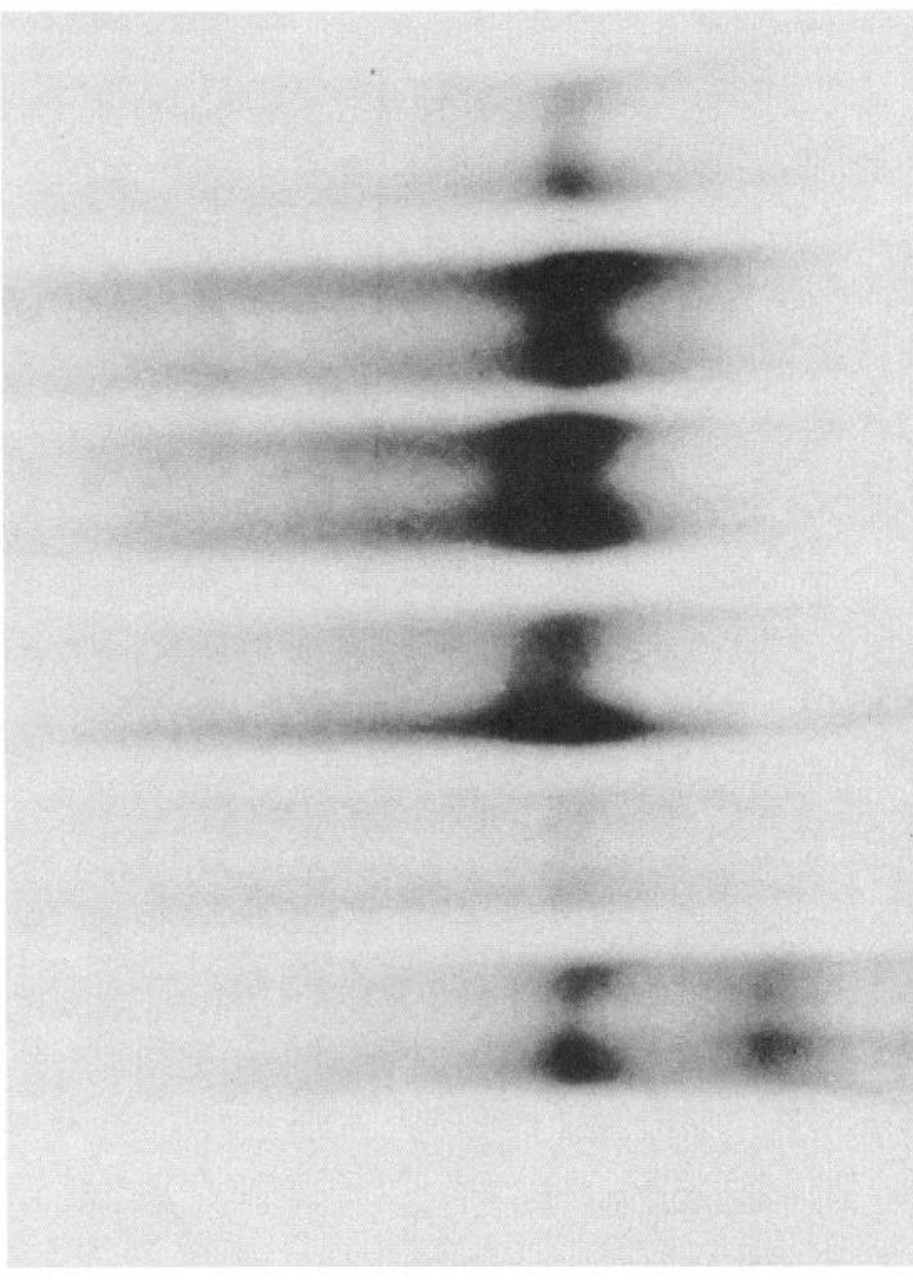

the expression of the $35 \mathrm{kDa}$ fra persisted for at least 2 weeks after KA administration. This protein is primarily expressed in the neurons of the dentate gyrus, indicating that these neurons may remain activated for a protracted time after the initial seizure activity. This transcription factor could be modulating long-term changes in gene expression in these neurons. Degenerating neurons in $\mathrm{CA} 1$ and $\mathrm{CA} 3$ also appear to express this protein, suggesting that the $35 \mathrm{kDa}$ fra could be involved in the regulation of genes during neuronal degeneration. Expression of transcription factors including the AP-1 factors is increased after brain injury (Gunn et al., 1990; Herdegen et al., 1992; Dragunow et al., 1993; Koistinaho et al., 1993; Smeyne et al., 1993) and during the process of apoptosis (Gonzales-Martin et al., 1992; Grassilli et al., 1992; Martin et al., 1992), suggesting these factors are involved in modulating genes involved in cell death.

The identity of the $35 \mathrm{kDa}$ fra is unknown. Antibodies produced against FosB and fra2, which were used to probe Western blots of the $35 \mathrm{kDa}$ fra, did not recognize this protein (data not shown). Furthermore, fra- 1 is not detected in the brain (Sonnenberg et al., 1989a; unpublished observations). Therefore, it is likely that the $35 \mathrm{kDa}$ fra is an unidentified member of the fra family. This transcription factor is the only member of the fra family that is induced in the striatum after repeated treatments with dopamine agonists (Pennypacker et al., 1992a). In contrast, there is only basal expression of a $35 \mathrm{kDa}$ fra-immunoreactive protein in the adrenal gland (Pennypacker et al., 1992b). Thus, this $35 \mathrm{kDa}$ fra could be involved in long-term

\section{C \\ KA}

NRS

NFJ
AP-1 Q-FRA BSA
Figure 6. AP-1 DNA binding activity to GFAP promotor sequence. An oligomer to a GFAP promotor AP-1 sequence was used in the gel shift assay using hippocampal extracts from saline-injected rats $(C)$ or rats 1 week after $\mathrm{KA}$ treatment $(K A)$. Extracts from KAtreated rats were preincubated with a 100 -fold excess of consensus AP-1 oligomer or antibodies specific to fra proteins $(\alpha-F R A)$ to show specificity of the DNA binding. Normal rabbit serum $(N R S)$ or a 100-fold excess of an unrelated oligomer $(N F J)$ did not affect DNA binding. Bovine serum albumin $(B S A)$ did not bind to the DNA probe. changes in gene expression in many different regions of the brain and other tissues.

Very few reactive astroglia in the $\mathrm{CA} 1$ and CA3 express the $35 \mathrm{kDa}$ fra; however, these regions contain elevated levels of AP-1 DNA activity. Antibodies produced against AP-1 proteins (JunD, JunB, c-jun, fra-2, FosB) do not affect this AP-1 DNA binding (unpublished observations) and the fra antibodies cause only a minor supershift, which may be due to the $35 \mathrm{kDa}$ fra expressed in the surviving neurons. JunD immunoreactivity determined by Western blotting is detected at relatively high basal levels and is not affected by the effects of kainate treatment. Antibodies against this protein that have been shown to work on the gel shift assay (Dr. M. Comb) do not affect the DNA binding activity. The DNA binding could derive from glialspecific transcription factors that recognize the AP-1 sequence. An elevated AP-1 DNA binding activity has been observed in several brain regions during the early postnatal period and subsequently declines to low adult basal levels by postnatal day 21 (Pennypacker et al., 1993b). This early postnatal AP-1 complex is unaffected by antibodies that recognize the fra proteins but does contain immunoreactivity to the cAMP-responsive element binding proteins, in which some members of this transcription factor family recognize AP-1 sequences (Hai and Curran, 1991). During the early postnatal period and reactive gliosis, the glia are undergoing morphological and biochemical changes, which implies the AP-1 DNA binding activity plays a role in modulating gene expression in glia during these periods. 
Kainate administration causes both short-term increases in AP-1 transcription factors, due to seizure activity, and longterm increases in AP-1 DNA binding activities in astroglia, due to neuronal damage, and in neurons of the dentate gyrus. The prolonged increases in AP-1 DNA activity in the dentate gyrus could be due to recurrent seizures; however, sedating the rats with pentobarbital for $6 \mathrm{hr} 1$ week after kainate administration has no effect on the increased DNA binding, suggesting that recurrent seizures are not responsible for this phenomenon or that the induction of AP-1 DNA binding is long lasting and slow to reverse. Most of the AP-1 proteins are induced initially (i.e., c-fos, c-jun, and a $46 \mathrm{kDa}$ fra), but their expression is undetectable by 2 weeks after $\mathrm{KA}$ administration. By 1 week after kainate administration, the hippocampus contains elevated levels of at least two different AP-1 DNA binding complexes. A $35 \mathrm{kDa}$ fra is a major component of the AP-1 complex in neurons of the dentate gyrus which may be regulating long-term changes in gene expression. In areas of reactive gliosis, elevated AP-1 DNA binding activity is observed that does not contain fra proteins in this DNA:protein complex. Although the transcription factors involved need to be identified, the high levels of AP-1 DNA binding activity in areas of reactive gliosis may be regulating changes in the expression of glial-specific genes such as GFAP.

\section{References}

Dragunow M, Robertson HA (1987) Generalized seizures induce c-fos protein(s) in mammalian neurons. Neurosci Lett 82:157-161.

Dragunow M, Young D, Hughes P, MacGibbon G, Lawlor P, Singleton K, Sirimanne E, Beilharz E, Gluckman P (1993) Is c-Jun involved in nerve cell death following status epilepticus and hypoxic-ischaemic brain injury? Mol Brain Res 18:347-352.

Eddleston M, Mucke L (1993) Molecular profile of reactive astrocytes-implications for their role in neurologic disease. Neuroscience 54:15-36.

Gonzalez-Martin C, De Diego I, Crespo D, Fairen A (1992) Transient c-fos expression accompanies naturally occurring cell death in the developing interhemispheric cortex of the rat. Dev Brain Res 68:8395 .

Grassilli E, Cacereri der Prati A, Monti D, Troiano L, Menegazzi M, Barbieri D, Francheschi C, Suzuki H (1992) Studies of the relationship between cell proliferation and cell death. II. Early gene expression during concanavalin A-induced proliferation or dexamethasone-induced apoptosis of rat thymocytes. Biochem Biophys Res Commun 188:1261-1266.

Gunn AJ, Dragunow M, Faull RLM, Gluckman PD (1990) Effects of hypoxia-ischemia and seizures on neuronal and glial-like c-fos protein levels in the infant rat. Brain Res 531:105-116.

Hai T, Curran T (1991) Cross-family dimerization of transcription factors Fos/Jun and ATF/CREB alters DNA binding specificity. Proc Natl Acad Sci USA 88:3720-3724.

Herdegen T, Fiallos-Estrada CE, Schmid W, Bravo R, Zimmmerman $M$ (1992) The transcription factors c-JUN, JUN D and CREB, but not FOS and KROX-24, are differentially regulated in axotomized neurons following transection of rat sciatic nerve. Neuroscience 14: 155-165.

Koistinaho J, Pelto-Huikko M, Sagar SM, Dagerlind A, Roivainen R, Hokfelt $T$ (1993) Injury-induced long-term expression of c-jun in the rat superior cervical ganglion. Neuroreport 4:37-40.
Le Gal La Salle G (1988) Long-lasting and sequential increase of $\mathrm{c}$-fos oncoprotein expression in kainic acid-induced status epilepticus. Neurosci Lett 88:127-130.

Martin DP, Ito A, Horigome K, Lampe PA, Johnson EM Jr (1992) Biochemical characterization of programmed cell death in NGF-deprived sympathetic neurons. J Neurobiol 23:1205-1220.

Masood K, Besnard F, Su Y, Brenner M (1993) Analysis of a segment of the human glial fibrillary acidic protein that directs astrocyte-specific transcription. J Neurochem 61:160-166.

Morgan J1, Curran II (1991) Stimulus-transcription coupling in the nervous system: involvement of the inducible proto-oncogenes fos and jun. Annu Rev Neurosci 14:421-451.

Morgan JI, Cohen DR, Hempstead JL, Curran T (1987) Mapping patterns of c-fos expression in the central nervous system after seizure. Science 237:192-197.

Nitsch C, Scotti AL, Monard D, Heim C, Sontag K-H (1993) The glia-derived protease nexin 1 persists for over 1 year in rat brain areas selectively lesioned by transient global ischaemia. Eur J Neurosci 5:292-297.

Pennypacker KR, Zhang WQ, Ye H, Hong JS (1992a) Apomorphine induction of AP- 1 DNA binding in the rat striatum after dopamine depletion. Mol Brain Res 15:151-155.

Pennypacker KR, Hong JS, Douglass J, McMillian MK (1992b) Constitutive expression of AP-I transcription factors in the rat adrenal. J Biol Chem 267:20148-20152.

Pennypacker KR, Walczak DD, Thai L, Fannin R, Mason E, Douglass J, Hong JS (1993a) Kainate-induced changes in opioid peptide genes and AP-1 protein expression in the rat hippocampus. J Neurochem 60:204-211.

Pennypacker KR, Dreyer D, Hong JS, McMillian MK (1993b) Elevated basal AP-1 DNA binding activity in developing rat brain. Mol Brain Res 19:349-352.

Popovici T, Represa A, Crepel V, Barbin G, Beaudoin M, Ben-Ari Y (1990) Effects of kainic acid-induced seizures and ischemia on c-foslike proteins in rat brain. Brain Res 536:183-194.

Sakaurai-Yamashita Y, Sassone-Corsi P, Gombos G (1991) Immunohistochemistry of c-fos in mouse brain during postnatal development: basal levels and changing response to metrozol and kainate injection. Eur J Neurosci 3:764-770.

Sar M (1985) Application of avidin-biotin complex technique for the localization of estradiol receptor in target tissue using monoclonal antibodies. In: Technique in immunocytochemistry, Vol 3 (Bullock GR, Putruz P, eds), pp 33-54. New York: Academic.

Simonato M, Hosford DA, Labiner DM, Shin C, Mansbach HH, McNamara JO (1991) Differential expression of immediate early genes in the hippocampus in the kindling model of epilepsy. Mol Brain Res $11: 115-124$

Smeyne RJ, Vendrell M, Hayward M, Baker SJ, Miao GG, Schilling K, Robertson LM, Curran T, Morgan JI (1993) Continuous c-fos expression precedes programmed cell death in vivo. Nature $363: 166$ 169.

Sonnenberg JL, Macgregor-Leon PF, Curran T, Morgan JI (1989a) Dynamic alterations occur in the levels and composition of transcription factor AP-1 complexes after seizure. Neuron 3:359-365.

Sonnenberg JL, Mitchelmore C, Macgregor-Leon PF, Hempstead J, Morgan JI, Curran T (1989b) Glutamate receptor agonists increase the expression of fos, fra, and AP-1 DNA binding activity in the mammalian brain. J Neurosci Res 24:72-80.

White JD, Gall CM (1987) Differential regulation of neuropeptide and proto-oncogene mRNA content in the hippocampus following recurrent seizures. Mol Brain Res 3:21-29.

Young ST, Porrino LJ, Iadarola MJ (1991) Cocaine induces striatal c-fos-immunoreactive proteins via dopaminergic $D_{1}$ receptors. Proc Natl Acad Sci USA 88:1291-1295. 